\title{
THE DEVELOPMENT OF LANGUAGE COMPETENCES WITH FUTURE CROATIAN TEACHERS WITHIN CROATIAN EDUCATION SYSTEM
}

\author{
Katarina Aladrović Slovaček \\ Faculty of Teacher Education, University of Zagreb \\ Anita Mazej \\ Osnovna škola Augusta Cesarca, Zagreb \\ Anđelka Ravlić \\ Trgovačka škola, Zagreb
}

\section{Abstract}

In the document "Eight key competences for life-long learning" the first and the most important competence is communication in the mother tongue. If we have good knowledge of mother tongue, then we will be better in the process of foreign language learning. Language competence means to know the language on the level of phonology, morphology, syntax, lexicology, orthography and orthoepy. We have linguistic competence (knowledge about language) and communicative competence (using of language). At this moment, when we speak about European society, it is very important to have good competences in ICT and foreign language speaking. For these reasons, we made this research about language competences in mother tongue (Croatian language) and English in primary school and the attitude of children to Croatian and English language and the way they learn them or not. The research includes 3 primary schools in Zagreb $(\mathrm{N}=120)$ in the first two periods of learning (1st - 6th class). Our aim is to measure linguistic and communicative competence in Croatian and English and how pupils are different in terms of sex, age and attitude. We expect that children in the first two periods of primary school have better developed linguistic competence (theory of language) than communicative competence (using language in everyday situations). It is expected because of methods of teaching and learning. Croatian teachers are more focused on theory than functional literacy in the process of teaching and learning of Croatian language. It is easier with English because teachers of English are more focused on using English in different situations. Also, we expect better results from girls than boys, from older than younger pupils as well as from pupils who have more positive attitudes to Croatian and English language.

Key words: teaching of Croatian language, language competences, eight key competences, primary school teachers, motivation 


\section{Introduction}

In the time of educational changes and the reform initiated in the Republic of Croatia this year (2015), it is important to place the development of language competences to the key position. As early as 2005 European Commission drew up the document „Eight Key Competences" defining the communication in mother tongue as the first and key competence and the communication in foreign language as the second key competence. Obviously, is the child masters its own mother tongue, especially all types of language activities: listening, speaking, reading and writing, it will be much easier for them to acquire the contents of other subjects, including the foreign language. It is, therefore, necessary to place the teaching of mother tongue (Croatian) and foreign (English) language to the key position in the curriculums of primary schools. In order to analyze the situation and the current knowledge of pupils, this paper is expected to determine the level of language (linguistic) and language communication (communicative) competence of pupils during the first two educational periods ( 2 nd -6 th) grade. For this purpose the tests were made for Croatian (mother tongue) and English (the first foreign language) checking the knowledge of language on both levels. The results were analyzed and compared in order to identify the necessary changes which should be part of the reform of Croatian educational system and language teaching. The said reforms, stimulating the enhancement of quality of the educational system, lead towards the goal of Croatian national educational framework, which is the knowledge oriented society. The knowledge oriented society is defined as the one based on the "types" of knowledge in the areas of innovation, research, education and training which should be the pivotal pillars within the European Union. The basic goals enabling achievement of such society are: to make a large number of illiterate people within the global population able to read and write, to make the learning available to everybody through the life-long learning, to improve the quality of education and introduce new technologies to education (e-learning, etc.). Redefinition of knowledge, in terms of the continuous learning process on defined educational levels, has a direct influence on reformation of educational policies with the aim to offer better possibilities of access to knowledge for all citizens, regardless of their age, place of residence and social status.

\section{About Croatian language}

Croatian language is one of Slavic languages (sub-group of South Slavic languages) spoken by 4.5 million people in the country and as many abroad. Since it is a small language, it can be said that the preservation of the language as the means of identity of the entire nation is important and therefore it is necessary 
to develop the awareness of its correct use. Just as all Slavic languages, Croatian language is morphologically rich: it has seven cases, three different genders, two different numerals, four past tenses, one present tense and two future tenses. The verbs are differentiated according to the verbal aspect, subject of activity, mode, status and aspect. The adjectives, as the changeable type of words, are differentiated according to the gender, number, case and aspect. The adjectives can be both declined and compared. Croatian language encompasses seven types of pronouns as well as numbers, numeral nouns, numeral adjectives and numeral adverbs (Silić and Pranjković, 2007). Regarding the area of phonetics and phonology, it is special for its sounds with diacritic signs which can be troublesome for the speakers both in speaking and writing. As for the written forms of expression, special problems are found in writing of the reflex of the proto-Slavic yat which has four different alternations: $\mathrm{ije} / \mathrm{je} / \mathrm{e} / \mathrm{i}$. The area of syntax is somewhat simpler since the choice of words and their position in the sentence is free, though the structure: subject + predicate + object is a classic structure which always functions in all forms of discourses. Croatian language differentiates five different functional styles of expression: scientific, administrative-business, conversational, literary-artistic and journalistic.

Each functional style has its own rules of writing which apply to the manner of writing, forming of text and choice of style and vocabulary. The lexis of Croatian language includes many words from Turkish, German, Hungarian and Italian languages due to historical, political and geographic circumstances in which the country lived in the past. Today, the influence of English language is significant in all areas of public life, including the spoken and written language and especially the public language, the language of the media. One of the basic goals of the mother tongue lessons on all education levels is the development of language competences, especially the language - communicative competence, therefore it is the target of this paper to present the results of research of language competences with Croatian students in primary school.

\section{Position of Croatian Language as a School Subject in Croatian Education System}

The standard form of Croatian language is started to be taught when the children enter school which usually happens about the age of seven. Croatian education system is divided into: kindergarten and preschool, primary school, secondary school and higher education. The children start learning the standard Croatian language when they enter the kindergarten, but this learning is done through different games and it is not systematic. The preschool period starts about the age of six and then the children in Croatian kindergartens start to prepare for initial reading and writing which is taught in the first grade of the primary school. At the age of 
seven, when they enter school, the children start with institutional learning of Croatian language as the mother tongue. The primary school is divided into two parts: junior grades (from the first to the fourth grade) and senior grades (from the fifth to the eight grade). In the first six grades, Croatian language is taught for five periods per week and in the final two grades for four periods per week. The secondary school education is divided into gymnasiums (comprehensive schools), vocational and art schools. Croatian language as the mother tongue is taught for four periods per week in gymnasiums and for three periods per week in other secondary schools. In primary school, the focus of teaching of Croatian language as the mother tongue is on grammar and orthography as well as the development of language - communicative competence since the pupils until the age of 12 (according to Piaget, 1977) are in the concrete operations stage. In the secondary school, the focus is on teaching the literature, with only few hours left for teaching the language (grammar and orthography) and language expression (written and oral). Croatian language as a school subject is divided into four areas: language (grammar and orthography), language expression, literature and media culture. On the academic level, Croatian language is taught only at faculties where future Croatian teachers are taught (faculties of philosophy, faculties of teacher education). Considering the importance of literacy in the mother tongue which is also stressed by the document "Eight Key Competences for Lifelong Learning", a need emerges for Croatian language to be introduced as a subject to all faculties. However, this is only an idea which, after numerous analyses, research and recommendations, has still not been implemented.

\section{About English language}

English is a member of the Germanic family of languages, while Germanic is a branch of the Indo-European language family. It has a rich history going back over a millennium and has been influenced by many languages, such as Celtic, French, Latin, Greek, Scandinavian languages such as Old Norse, Dutch, Spanish, Italian, Indian, German, Hebrew, Yiddish and Arabic.

Nowadays, English is the single most important language in the world, being the official or de facto language of the United Kingdom, the United States of America, Canada, Australia, New Zealand, South Africa and dozens of others, and being the lingua franca of the Internet. Many varieties of English are spoken around the world - from lectures in graduate school in Holland to parliamentary proceedings in Papua New Guinea - but interestingly the vast majority of the variation lies in pronunciation and vocabulary. The number of differences in grammar between different varieties of Standard English is very small indeed relative to the full range of syntactic constructions and morphological word-forms. 
Nevertheless, there undoubtedly are differences of this kind that need to be noted. For example, the use of the verb do following an auxiliary verb, as in I'm not sure that I'll go, but I may do is not found in American English, and conversely the past participle verb-form gotten, as in I've just gotten a new car, is distinctively American.

The regional dialects of Standard English in the world today can be divided into two large families with regional and historical affinities. One contains standard educated Southern British English, henceforth abbreviated BrE, together with a variety of related dialects, including most of the varieties of English in Great Britain, Australia, New Zealand, South Africa, and most other places in the British Commonwealth. The second dialect family is referred to as American English, henceforth AmE - it contains the dialects of the United States, Canada, and associated territories, from Hawaii and Alaska to eastern Canada.

\section{Position of English Language as a School Subject in Croatian Education System}

Croatian children make their first official school contact with English language at the moment when they enter primary school. However, all of them have already heard or even spoken the language before. Some have attended foreign language courses for pre-school children, some have relatives or friends who speak English and almost absolute majority has heard it on TV and the radio.

From the 1st to 4th grade (junior grades) of primary school, English language is taught for two lessons of 45 minutes per week which adds up to 70 lessons per school year. In the 1st grade, the teaching methods are very similar to the ones used in pre-school courses. There is practically no writing, almost all language content being oral and taught through songs, simple games and TPR (total physical response) activities. Writing and reading is gradually introduced from the 2 nd to the 4 th grade, the emphasis still being on orally transmitted contents.

From the 5th to 8 th grade (senior grades) of primary school, English is taught for three lessons of 45 minutes per week which adds up to 105 lessons per school year. All four language activities, speaking, listening, reading and writing, should be equally represented with one sole aim: to enable pupils to be able to communicate. Very little linguistic competence is required in terms of language theory.

This aim does not change in secondary school, though the final achievement and the level of communicative competence of students will generally depend on their choice of school. There are two types of secondary schools in Croatia: gymasi- 
ums or comprehensive schools where English is mostly taught for 3 lessons per week in all four grades and vocational schools with 3 lessons per week, but only in the first two grades. For this reason, there is generally a significant difference in the national exam results (matura) of gymnasium and vocational school students.

On the academic level, English is taught at all Croatian faculties, its curriculum depending on the particular faculty.

As a conclusion, it should be pointed out that, as it concerns English language, one common feature is shared throughout Croatian educational system and that is communicative competence, while linguistic competence is reserved for future English language teachers only.

\section{Language competences (defining and targets)}

The word "competence" comes from the Latin word "competare" (verb) which means achieve, be better (Anić, 2001). The language competences are divided into the linguistic (language) and communicative (communicative language) competence. Both of them are important and therefore stimulated, especially through the teaching of Croatian language, but also through other subjects. The communicative competence was formed in the 80's of the 20th century when Dell Hymess (1980) defined it as the ability of the speaker to choose the most appropriate out of different language sub-systems. The communicative competence implies application of language knowledge in actual situations. It includes practical and functional language knowledge while the Common European Framework of Reference for Languages: Learning and Teaching, (2005) considers that the communicative competence consists of the linguistic, sociolinguistic and pragmatic competence. Linguistic competence implies knowledge of language and its rules, sociolinguistic implies use of these rules in certain discourses defined by the society, while the pragmatic one implies use of language in certain functions, for example through language activities of speaking, listening, reading and writing. Different authors define the communicative competence in different ways, so Martinet (1982) defines the communicative competence as a capacity on the level of functional language application (functional linguistics). Yule and Levinson (2003) define the communicative competence as pragmatics which includes applicable and pragmatic knowledge of language. Canale and Swain (1980) define the communicative competence as a synthesis of the basic system of knowledge and skills necessary for communication (three types of knowledge: about basic grammar principles, how the language is used in social contexts and how communicative functions can be connected in view of the discourse principles). Trask (2005) defines the communicative competence 
as the ability of appropriate expression in social circumstances. As opposed to the communicative competence, Chomsky defined the linguistic (language) competence as the knowledge of language, language rules and standards. He makes a difference between the language performance which would be adequate to the communicative competence (it implies communicative knowledge of language) and the language competence (which implies theoretic knowledge of language).

The basic target of Croatian language teaching on all education levels is to train the student for language communication which would enable them to learn the contents of other subjects and to be included into the lifelong education. Among other targets, we can single out the one which says that it is necessary to develop language communicative abilities, which implies the development of language competences. Speaking about the students of the Faculty of Teacher Education, it can be said that it is necessary to develop both competences: the knowledge of language implied by the linguistic competence and the use of this knowledge in actual situations implied by the communicative competence. Unambiguously, language competences would imply the knowledge of language and the ability of communication, both written and oral, in a certain language.

\section{Research}

\section{Targets of Research}

The basic target of the research was to investigate the language competences of Croatian pupils in English and Croatian. In accordance with the basic target, five problems - targets of the research have been set:

1. To investigate whether there is a statistically significant difference in the results of the linguistic and communicative competence in the knowledge of Croatian language.

2. To investigate whether there is a statistically significant difference in the results of the linguistic and communicative competence in the knowledge of English language.

3. To investigate whether there is a statistically significant difference in the knowledge of grammar of Croatian language (phonetics and phonology, morphology, syntax, lexicology) and the orthography of Croatian.

4. To investigate whether there is a statistically significant difference in the total knowledge of Croatian and English, the level of communicative and the level of the linguistic competence in relation to age and sex.

5. To investigate the attitude of students about Croatian and English language as a school subject. 


\section{Hypotheses of the Research}

In connection with the research targets, the following hypotheses were set:

1. It is expected that there is a statistically significant difference between the linguistic and communicative competence in the knowledge of Croatian language.

2. It is expected that there is a statistically significant difference between the linguistic and communicative competence in the knowledge of English. We expected the level of communicative competence in English to be more developed.

3. It is expected that there is a statistically significant difference in the knowledge of grammar and orthography of Croatian language (the students know the grammar better).

4. It is expected that there is a statistically significant difference in the total knowledge, the level of linguistic and communicative competence depending on the sex and age. Girls and older students are expected to be more successful.

5. It is expected that the examinees consider Croatian and English language as very important subjects in their education.

\section{Methodology of Research}

The sample consisted of the students from three different primary schools in Zagreb $(\mathrm{N}=120)$. All examinees wrote a written examination of knowledge by which the communicative and linguistic competences were assessed, according to the following grammar areas: phonetics and phonology, morphology, syntax, lexicology as well as orthography and language history. After the test of knowledge, the examinees completed an on-line questionnaire on their attitude to Croatian language and English as school subjects in general. The data have been processed in the SPSS statistics programme by means of parametric methods (analysis of variance, $t$-test) and non-parametric methods (H2 test, arithmetic means).

\section{The Research Results}

\section{The Knowledge of Language Competences - Croatian}

The language competences, which have already been defined as the ability to use the language in actual situations and the knowledge of language theory, have been tested with the students of primary school to the 6th grade. The t-test shows that there is a statistically significant difference in the results of the linguistic and communicative competence on the significance level of $5 \%$ (chart 1). Since the Croatian education system is directed more to learning the language theory and less to development of communicative competence as the language application, the expected results are in favour of the linguistic competence. To conclude, the students 
know the language theory (definitions, theorems) better than the application of the said theory in actual situations. A similar research was made with primary school pupils (Pavličević-Franić, Aladrović, 2009) and the results showed that the primary school pupils also know the language theory better than the application of the said theory in actual communicative situations which is obviously reflected in the future education and probably influences the manner of teaching of Croatian language as the mother tongue. The above-mentioned data point to the fact that the first hypothesis stating that the difference between the linguistic and communicative competence in knowledge of Croatian language is expected to be statistically significant has been confirmed.

Chart 1 Results of linguistic and communicative competence in knowledge of Croatian

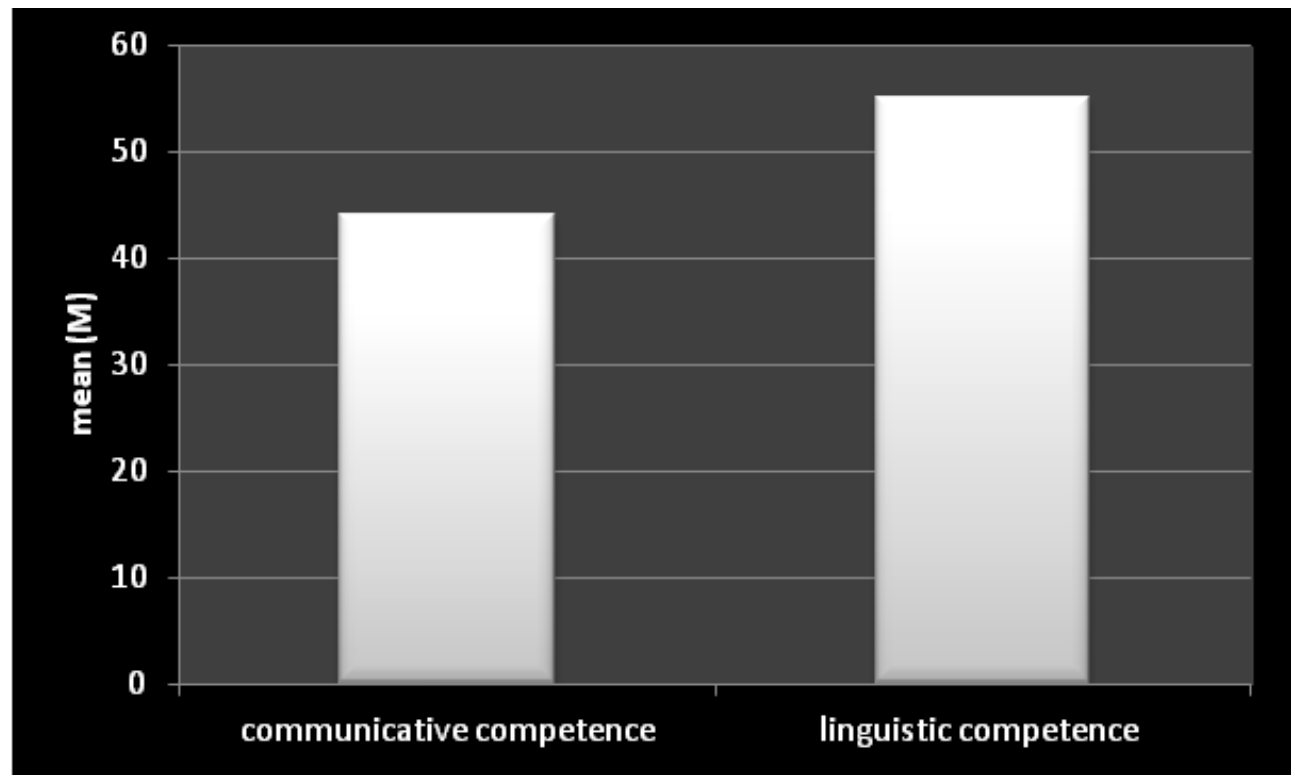

\section{The Knowledge of Language Competences - English}

The t-test shows that there is a statistically significant difference in the results of the linguistic and communicative competence on the significance level of 5\% (chart 2) in the process of learning English. Better results were achieved on the communicative competence level which implies the functional knowledge of language. This is no surprise considering the communicative manner in which English language is taught throughout Croatian schools, primary and secondary ones. The sole aim of the learning process is to enable the pupils to communicate, both orally and in writing. Teaching methods are adapted to this aim, including a lot of conversation, games and game-like activities. Very little linguistic content is required and only for the purpose of better explanation of communicative activities. Therefore, as expected, the second hypothesis was confirmed. 
Chart 2 Results of linguistic and communicative competence in knowledge of English



\section{Difference in knowledge of orthography and grammar}

The results are divided into grammar contents (phonetics and phonology, morphology, syntax and lexicology), orthographic contents and the contents from the history of Croatian language. The results show that the examinees best solved the tasks related to lexicology ( $79 \%$ of the tasks solved) and then the tasks related to the knowledge of phonetics and phonology (65\% solved). The pupils also show a solid knowledge of language history ( $62 \%$ of the test solved). It is interesting that the worst solved was the part of the test related to the knowledge of syntax (43\% of the test solved). Morphology, one of the most demanding areas of grammar, was solved on the 59\% level. The orthographic rules (sounds č and ć, dž and đ, writing of diphthong ije/je, capital and small letter, punctuation) also caused a lot of trouble to the examinees, therefore the test was solved on the 55\% level (table 1).

Table 1 Test results in grammar and orthography

\begin{tabular}{|l|l|}
\hline $\begin{array}{l}\text { THE AREA OF CROATIAN LANGUAGE } \\
\text { CURRICULUM }\end{array}$ & TEST RESULTS (IN \%) \\
\hline PHONETICS AND PHONOLOGY & $65 \%$ \\
\hline MORPHOLOGY & $59 \%$ \\
\hline SYNTAX & $43 \%$ \\
\hline LEXICOLOGY & $79 \%$ \\
\hline HISTORY OF CROATIAN LANGUAGE & $62 \%$ \\
\hline ORTHOGRAPHY & $55 \%$ \\
\hline
\end{tabular}


When, through the t-test, the test results are compared regarding the grammar knowledge (phonetics and phonology, morphology, syntax and lexicology) and the knowledge of orthography, the result is the difference which can be announced statistically significant on the significance level of 5\%. The examinees show statistically significantly better results in knowledge of grammar than the knowledge of orthography (chart 3). Another large problem for students is writing of the words with the sounds č and ć, dž and d and writing of the diphthong ije/je, as well as the writing of capital and small letter and punctuation. This can be a proof of the third hypothesis which states that a statistically significant difference is expected in knowledge of grammar and orthography of Croatian language (the students know the grammar better). The reason for this can be orthographic ambiguities which have still not been resolved and which confuse the examinees and the students who learn Croatian language.

\section{Difference in knowledge and language competences with regard to the age and sex}

The F-test shows that there is a significant difference in the total results, depending on the age, on the significance level of $5 \%$ (table 2), but the F-test also shows that there is a statistically significant difference in the results depending on the age in relation to the test of communicative and the test of linguistic competence, i.e. the results are very close to the level of significance, therefore they can be proclaimed statistically significant. The T-test shows that there is a significant difference in the total results depending on the sex. Girls are better in total results than boys and in results on the test of communicative and linguistic competence. This partially confirmed the fourth hypothesis assuming better results of girls and older pupils.

\begin{tabular}{|l|l|l|l|l|}
\hline & F-test & SIG. $(\mathrm{p}<0,05)$ & T-test & SIG. $(\mathrm{p}<0,05)$ \\
\hline Total results & 3,29 & 0,026 & 2,58 & 0,002 \\
\hline $\begin{array}{l}\text { Test of commu- } \\
\text { nicative compet- } \\
\text { ence }\end{array}$ & 2,62 & 0,058 & 3,45 & 0,005 \\
\hline $\begin{array}{l}\text { test of linguistic } \\
\text { competence }\end{array}$ & 2,61 & 0,060 & 1,25 & 0,004 \\
\hline
\end{tabular}

\section{Attitude/Opinion of Students about Croatian Language and English}

The results show that pupils prefer Croatian to English language as a school subject. The assumption is that English language is foreign to them and requires more effort and work in the early learning phase. Though positive atti- 
tude towards both subjects is generally frequent, it is important to stimulate and motivate such attitude through both Croatian and English language lessons.

Chart 3 The attitude to English and Croatian as school subject (Liker scale 1 to 5)

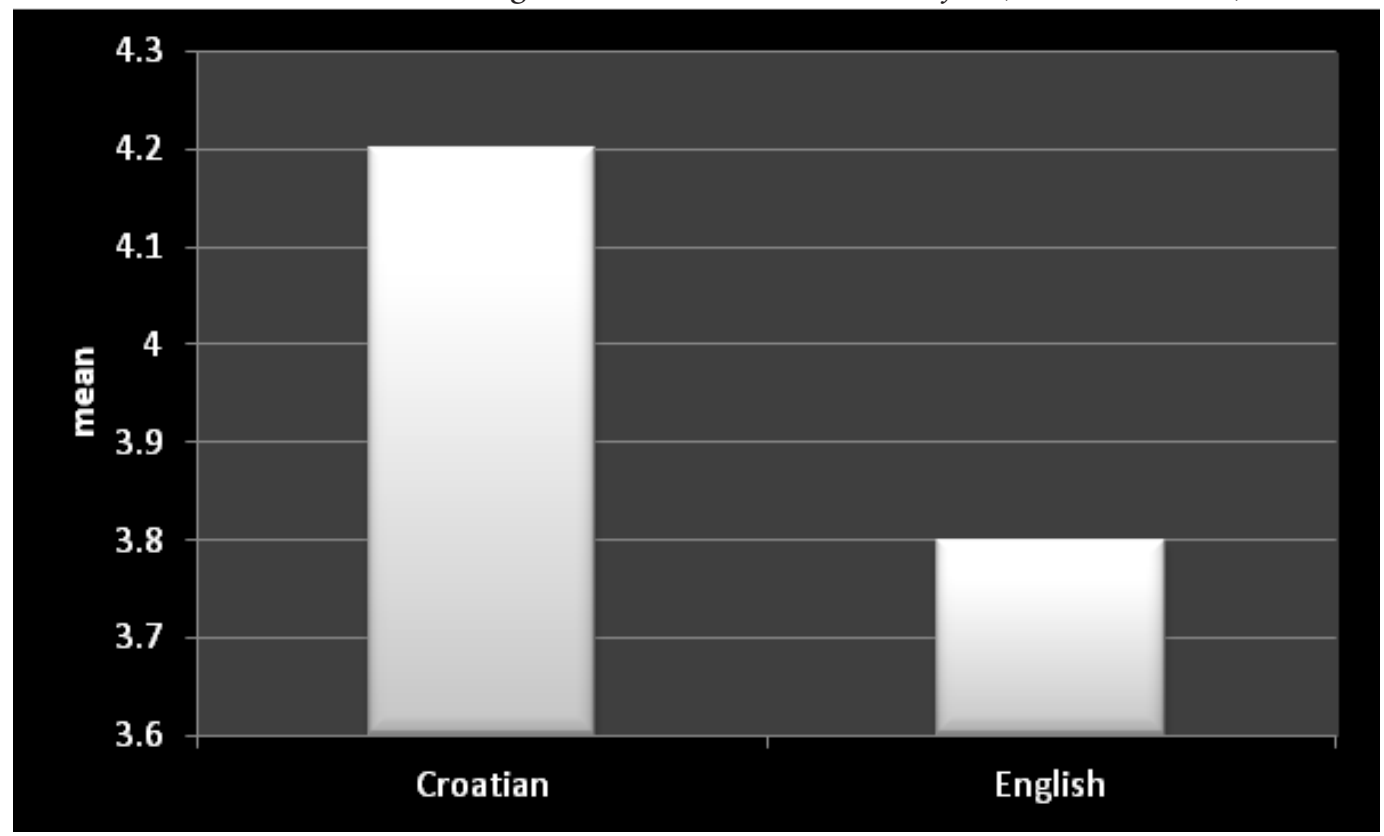

\section{Self-Estimate of Students about Own Knowledge of Language}

All examinees completely agree with the statement that the knowledge of Croatian language is important for them. However, they estimated their knowledge as very good and they very similarly estimated their competence for their future. This would mean that the examinees consider the knowledge of mother tongue important, but they do not feel competent about this knowledge (chart 4). The estimate of own knowledge or the self-estimate was the hardest task that the examinees had to perform since it is always subject to bias. However, most of examinees consider themselves the most competent in orthography, which can hardly be related to the real knowledge of orthography which the examinees showed at the test of knowledge. It is assumed that most of examinees wish to be communicatively competent since this competence is set as one of the key competences for facing the everyday life situations and therefore most examinees estimated themselves as communicatively competent person (chart 4). Along with the communicative competence and the knowledge of orthography, as an important element of their knowledge, the examinees point out their grammar knowledge which, just as in the case of orthography, is not in correlation with the results which the examin- 
ees showed at the tests of knowledge. It is interesting that in their self-estimate, as the fourth, very strong element, they point out the written competence which, on the higher level, unifies all language and text competences. However, this competence has not been checked by this test, therefore no correlation can be done.

Chart 4 Estimate of own knowledge of Croatian language



The results confirm the fifth hypothesis which assumed that the students would estimate their knowledge of Croatian language as very good, which they did, on the average (chart 4).

\section{Conclusion}

Communication in mother tongue is the first and the key competence for lifelong learning, therefore sufficient attention has to be paid to its stimulation and development on all education levels, including the academic level. It is especially important to work on this competence in mother tongue with the students who will themselves in the near future be in the position to develop the same language competences in mother tongue with their own pupils. The learning of language implies the language activities of reading, writing, speaking and listening in mother tongue, which, apart from learning the mother tongue, also help in acquisition of other contents and even in learning of other foreign languages. The knowledge about the importance of communication in mother tongue and development of language competences should be seen through the curriculum of the faculty of teacher edu- 
cation. As already mentioned, students of the faculty of teacher education, have only four language courses in their entire schooling, while the students attending the Croatian language module have eight obligatory courses from the area of their mother tongue. Absurdity of this situation lies in the fact that all students, after graduating from the faculty, work as primary school teachers from the 1st to the 4th grade and teach five hours of Croatian language per week, Croatian language being the most comprehensive subject of the school curriculum. The curriculum should be changed and the students of the faculties of teacher education should have more language courses so they could, through their studies, develop their language competences on a higher level. The students are aware of the importance of quality knowledge of the mother tongue, but they are also aware of their lack of knowledge and therefore they do not feel fully competent for their future job. For this reason, it is necessary to work on improvement of the quality of education in the mother tongue, increase of the number of mandatory courses, but also the elective courses which would provide all interested students with the opportunity of additional work. It is especially important that the students develop communicative competence in all areas of their mother tongue because good understanding stimulates transfer of knowledge in a quality manner. This research also opens one of the problems of the concept of the plan and programme of the faculty of teacher education after the Bologna process implementation. The change of the curriculum and introduction of a larger number of language courses would make the future Croatian teachers feel more competent for performance of their future teaching profession and thus create "a quality school" where each and every pupil will feel accepted and happy, while the teacher will feel secure and competent. 


\section{References}

Anić, V. (2001). Rječnik hrvatskoga jezika. Zagreb: Liber.

Canale, M. and Swain, M. (1980). Theoretical bases of communicative approaches to second lanuguage teaching and testing. Applied Linguistics 1, 1-47.

Chomsky, N. (1967). Knowledge of Language: Its Nature, Origin and Us. New York: Praeger. Curriculum (2006). Zagreb: MZOS. (12th June 2010 www.mzos.hr)

European Framework of References for Lifetime Learning, Teaching Goals and Methods:

Comunicative Competence. 12th September 2010 http://www.ucrlc.org/essentials/goal methods/goal.htm

Hymess, D. (1980). Etnografija komunikacije. Beograd: BIGZ.

Martinet, A. (1982). Osnove opće lingvistike. Zagreb: Grafički zavod Hrvatske.

Pavličević-Franić, D. (2005). Komunikacijom do gramatike. Zagreb: Alfa.

Pavličević-Franić, D. and Aladrović, K. (2009). Rano učenje hrvatskoga jezika 2. D.

Pavličević-Franić i A. Bežen (ur.), Psiholingvističke i humanističke odrednice u nastavi hrvatskoga jezika. Zagreb: ECNSI i Učiteljski fakultet Sveučilišta u Zagrebu, 165- 186.

Piaget, J. (1969). Intelektualni razvoj deteta. Beograd: Zavod za izdavanje udžbenika.

Pilić, Š. (2008). Obrazovanje u kontekstu tranzicije. Zagreb: Biblioteka školskog vjesnika.

Silić, J. and Pranjković, I. (2007). Gramatika hrvatskoga jezika. Zagreb: Školska knjiga.

Trask, R. L. (2009). Temeljni lingvistički pojmovi. Zagreb: Školska knjiga.

Unesco-ovo svjetsko izvješće. (2007). Prema društvima znanja. Zagreb: Educa.

Zajednički europski referentni okvir za jezike: učenje, poučavanje, vrednovanje (2005). Zagreb:

Školska knjiga.

Yule, G. (2003). The Study of Language. Cambridge: Cambridge university Press.

Huddleston, R. and Pullum, G.K. (2002). The Cambridge Grammar of the English Language.

Cambridge: Cambridge university Press. 